\title{
25. Translation Bibliomigrancy: The Case of Contemporary Caribbean Literature in Scandinavia
}

Yvonne Lindqvist

Translation Studies, Stockholm University

This paper presents the theoretical framework for the project The Meeting of Literary Peripheries by means of Translation Prerequisites for Caribbean Literature in Scandinavia. The framework is derived from the so-called "social turn" of translation studies where the general aim according to Wolf is: ${ }^{\mathrm{I}}$

... to contribute to the conceptualisation of a general translation sociology and ... to deliver a comprehensive methodological framework, substantiated by empirical studies, which would allow us to analyse the social implications of the translation process in its various contexts. ${ }^{2}$

This general translation sociology is based on the cultural sociology of Pierre Bourdieu as further developed by for instance

I Michaela Wolf, "Translating and Interpreting as a Social Practice Introspection into a New Field", in Übersetzen-Translating-Traduire: Towards a "Social Turn"? ed. Michaela Wolf (London: Transaction Publishers, 2006), 9-23.

2 Wolf, "Translating and Interpreting as a Social Practice", 9.

How to cite this book chapter:

Lindqvist, Yvonne. "Translation Bibliomigrancy: The Case of Contemporary Caribbean Literature in Scandinavia”. In World Literatures: Exploring the Cosmopolitan-Vernacular Exchange, edited by Stefan Helgesson, Annika Mörte Alling, Yvonne Lindqvist, and Helena Wulff, 295-309. Stockholm: Stockholm University Press, 20I8. DOI: https://doi.org/Io.I6993/bat.y. License: CC-BY. 
Pascale Casanova, John Heilbron and Giséle Sapiro. ${ }^{3}$ It is commonly conceived of as hosting three main research areas: I) the sociology of translators 2) the sociology of translating 3) the sociology of translations. The first area deals with translator status, prestige and working conditions. The second studies the act of translating - the translation process, practices and norms. The third area studies translations as products on an international market. ${ }^{4}$ The current research project belongs mainly within the third area of research within the sociology of translations. It examines the uneven and hierarchical "flows" of literature in the "world republic of letters" materialised in translation. Considered from a sociological perspective, translations are a function of the social relations between language groups and their transformations over time. ${ }^{5}$

Cultural exchanges such as translation have their own dynamics largely depending on the global market structures. Hence, the project constructs the market as a relatively autonomous global field with economic, political and symbolic dimensions. More specifically, the project examines the prerequisites for the meeting by means of translation of two local literary peripheries on the global translation field. It explores the necessary

3 Pascale Casanova, La république mondiale des lettres (Paris: Éditions du Seuil, I999); Pascale Casanova, "Consécration et accumulation de capital littéraire. La traduction comme échange inégal”, Actes de la recherche en sciences sociales, I44 (2002); Johan Heilbron, "Towards a Sociology of Translation. Book Translations as a Cultural World System”, European Journal of Social Theory 2 (I999): 429-44; Johan Heilbron, "Responding to Globalization: The Development of Book Translations in France and the Netherlands", in Beyond Descriptive Translation Studies. Investigations in Homage to Gideon Toury ed. Anthony Pym, Miriam Shlesinger \& Daniel Simeoni.(Amsterdam/Philadelphia: Benjamins Translation Library, 2008), I87-99; Gisèle Sapiro, ed. Translatio: Le marché de la traduction en France à l'heure de la mondialisation (Paris: CNRS, Collection Culture et Société, 2008). Gisele Sapiro, “Globalization and Cultural Diversity in the Book Market: The Case of Literary Translations in the US and in France", Poetics 38 (2010), 4I9-39.

4 Andrew Chesterman, "The Name and Nature of Translator Studies", Hermes 42 (2009), I 6.

5 Heilbron, "Towards a Sociology of Translation", 43 I. 
consecration mechanisms for translation taking place from one local periphery to another, Caribbean to Scandinavian literature. Consecration is a term from the cultural sociology of Pierre Bourdieu, which in short means recognition and legitimation by the agents of the field under study. ${ }^{6}$ To be consecrated by autonomous agents on the literary field signifies the crossing of a literary border - a metamorphosis of ordinary (literary) material into "gold", into absolute literary value. And translation is from a global point of view a form of consecration. It constitutes the principal means for access to the literary world for writers outside the centre. ${ }^{7}$

The aim of the project is to examine the bibliomigrancy dynamics on the global translation field. Bibliomigrancy is an umbrella term that describes the migration of literary works in the form of books from one part of the world to the other. ${ }^{8}$ The term comprises two strands:

- Physical migration of books, i.e. book production and trade, translations, library acquisitions and circulation.

- Virtual migration, i.e. adaptations and appropriation of narratives; in more recent times the technical term for digitalisation of books.

Bibliomigrancy promotes and facilitates the processes of a "worlding" 9 of literature - the most basic condition for connections between central and peripheral positions on the global translation field. Translation gives a wider audience to this "world-making" by helping literary texts to escape the confines of the national

${ }^{6}$ Pierre Bourdieu, Konstens regler. Det litterära fältets uppkomst och struktur (Stockholm: Symposion, 2000), 326-27.

7 Pascale Casanova, The World Republic of Letters, trans. M B. DeBevoise (Cambridge: Harvard University Press, 2004), I 26.

8 Venkat Mani, "Bibliomigrancy: Book Series and the Making of World Literature", in The Routledge Companion to World Literature, ed. Teo D'haen, David Damrosch and Djelal Kadir (London and New York: Routledge 20I4), 289.

9 Pheng Cheah, "What is a World? On World Literature as World-Making Activity", Doedalus 3 (2008): 34-25. 
borders from which they have emerged to enter other contexts. ${ }^{\text {IO }}$ The bibliomigrancy concept encapsulates both the material and ideational dimensions of literary cosmopolitanism.

One methodological step in the study of translation bibliomigrancy dynamics is to test the double consecration hypothesis ${ }^{\text {II }}$ stating that this kind of literature needs to be consecrated primarily within the centre(s) of the former colonial power, and secondly - due to the strong impact of the Anglo-American culture and literature in Scandinavia - within the British and American literary cultures. Caribbean literature written in French, Spanish and English has to be "filtered", so to speak, through the central British and American cultures in order to reach Scandinavian readers in translation. The relations are schematically represented in figure 5 showing the bibliomigrancy dynamics of Caribbean and Scandinavian literatures.

Nevertheless, each Caribbean language group will probably manifest a specific dynamic depending on how centralised the contemporary literary culture in question is. Casanova has shown that the French literary culture is strongly mono-centric with Paris as the sole consecration centre. ${ }^{\mathrm{I2}}$ The English contemporary literary culture on the other hand is hypothesised in this study as duo-centric counting New York and London as the most important consecration centres. The Spanish contemporary literary culture eventually, is hypothesised as pluri-centric in the sense that literary consecration takes place in several centres alike, notably in Madrid, Barcelona, Mexico City and Buenos Aires for example. However, the British and American "filters" for reaching Scandinavia will be a common denominator for the involved

ro Kathryn Batchelor, "Translation: Spreading the Wings of Literature”, in Intimate Enemies. Translation in Francophone Contexts, ed. Kathryn Batchelor \& Claire Bisdorf (Liverpool: Liverpool University Press, 20I3), IO०.

is Yvonne Lindqvist, "Det globala översättningsfältet och den svenska översättningsmarknaden. Förutsättningar för litterära periferiers möte”, in Läsarnas marknad, marknadens läsare. En forskningsantologi utarbetad för litteraturutredningen, ed. Ulla Carlsson and Jenni Johannisson (NORDICOM. Göteborgs universitet, 20I2), Io.

I2 Casanova, Consécration et accumulation, 7-20. 


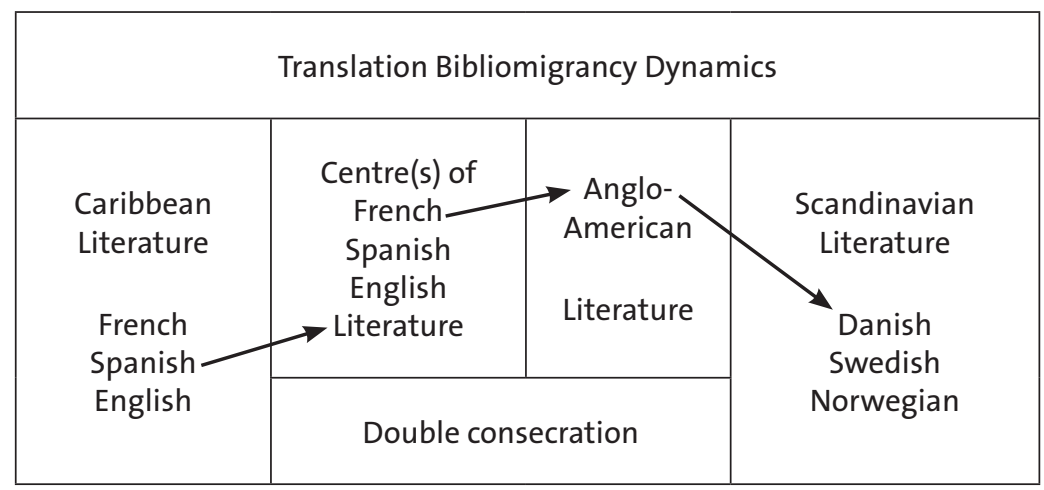

Figure 5. Schematic representation of the double consecration hypothesis concerning bibliomigrancy dynamics of Caribbean and Scandinavian literatures. ${ }^{\mathrm{I}}$

literary cultures in order to be translated into the Scandinavian languages. These complex dynamics probably also vary over time and according to genre. The project covers cosmopolitan and vernacular translation dynamics, i.e. literary migration on the global translation field from mainly dominated positions to the dominating in the first case, and from dominating to dominated in the latter, during the period I990-20I0.

Consequently, the hypothesis of the study claims that for this kind of literary translation to take place double consecration within the dominating cultures for each language group on the global translation field is necessary, i.e. writers from peripheral cultures selected for translation into Swedish, Danish and Norwegian have to be consecrated within the centre(s) of their previous (colonial) culture on the global translation field and then within the centres of the British and American cultures. The hypothesis is a specification of a more general hypothesis put forward by Heilbron, Casanova and Moretti: Literature translated from one periphery to another is a consequence of what is translated from the peripheral language in question to the central languages and cultures and

${ }^{13}$ An earlier version of the schematic representation of French Caribbean literature as an example has been published in Lindqvist 2012. 
that, as Moretti puts it, "movement from one periphery to another (without passing through the centre) is almost unheard of". ${ }^{14}$

\section{Centre and Periphery Relations on the Global Translation Field}

In order to map out the bibliomigrancy dynamics on the global translation field power relations between language groups have to be taken into consideration. As Mona Baker ${ }^{15}$ has pointed out, translation is rarely the peaceful linear transfer of literary and semantic devices described in textbooks in translation. On the contrary, the global translation field has its own rules of functioning based on positions gained from constant struggles of accumulated symbolic power.

One of the most cited databases for statistically surveys of the most dominating - hence most central - source languages on the global translation field is Index Translationum of UNESCO. The percentages in Table I are compiled from the findings of Heilbron and Sapiro and then compared to the numbers from 2015 in Index Translationum of UNESCO. ${ }^{16}$ Table I shows that the ranking of centrality in the global translation field has not changed essentially during the last 30 years in the central positions except for the decline of Russian in the I990s - English, French, and German remain as the hyper-central and central languages, respectively. Some minor alterations concern the semi-central languages. Spanish and Italian have changed place in terms of importance comparing the I990s and 2015 and Danish has lost ground from the seventh position of importance in I980s to the

${ }^{14}$ Heilbron, "Towards a Sociology”, 437; Casanova, Consécration et accumulation, 8; Franco Moretti, “More Conjectures”, New Left Review 20 (2003): 76.

I5 Mona Baker, "Editor's Introduction”, in Critical Readings in Translation Studies. ed. Mona Baker (London and New York: Routledge, 2010), 285.

I6 Heilbron, "Towards a Sociology", 433-35; Sapiro, "Translatio", 68-72, 423. For a discussion of the reliability of this database, see for instance Heilbron, "Globalization"; Sapiro, Translatio; Johan Svedjedal (ed.), Svensk litteratur som världslitteratur: en antologi (Uppsala: Uppsala University, 20I2). 
Table 1. The ten most central source languages on the global translation filed during the period I980-20 I 5. Percentage of the source language of the total amount of published books on the global translation market. ${ }^{17}$

\begin{tabular}{|c|c|c|c|c|c|}
\hline \multicolumn{2}{|c|}{$\begin{array}{l}\text { I980-I989 } \\
\text { (Heilbron I999) }\end{array}$} & \multicolumn{2}{|c|}{$\begin{array}{l}\text { I990-I999 } \\
\text { (Sapiro 2008) }\end{array}$} & \multicolumn{2}{|c|}{$\begin{array}{l}\text { Index Translationum } \\
2015^{18}\end{array}$} \\
\hline Language & Percentage & Language & Percentage & Language & Percentage \\
\hline English & 40 & English & 59 & English & 63 \\
\hline French & I 2 & French & IO & French & IO \\
\hline German & I I & German & IO & German & 9 \\
\hline Russian & IO & Spanish & 3 & Russian & 5 \\
\hline Italian & 3 & Italian & 3 & Italian & $3 \cdot 5$ \\
\hline Spanish & 3 & Swedish & 2 & Spanish & 3 \\
\hline Danish & 2 & Japanese & 2 & Swedish & 2 \\
\hline Swedish & 2 & Latin & 2 & Japanese & I. 5 \\
\hline Polish & I & Russian & I. 5 & Danish & I \\
\hline Czech & I & Danish & I & Latin & I \\
\hline
\end{tabular}

tenth in I990 - surpassed by Japanese and Latin - and to the ninth position in the year 2015. The climb of Latin on the scale in the I990s can probably be ascribed to a worldwide increase of translation of the literary classics and other medieval text genres for educational use. ${ }^{19}$

${ }^{17}$ I am aware of the fact that Table I is rather unorthodox. The data in the overview shown should only be interpreted as indications of tendencies in the global translation field, since exact numbers are virtually impossible to produce. An earlier version of this table has been published in Lindquist 2015.

${ }^{18} \mathrm{http}: / /$ www.unesco.org/xtrans/bsstatexp.aspx? $\operatorname{crit} \mathrm{IL}=3 \& \mathrm{n} T y \mathrm{p}=\min \&$ topN $=50 \& \lg =0$ accessed 25 November 2016.

19 Emily Wilson, "Translating the Classics". Society for Classical Studies 20I4, http://apaclassics.org/blogs/emilywilson/translating-classics\#sthash. rUe8ppAr.dpuf accessed I6 October 2016. 
The tendency in the global translation field is towards greater diversification of the amount of source languages mainly due to the decline of the Russian language from I I per cent in the I980s to I. 5 per cent in the I990s, shifting from a central position to a semi-central position and then gaining ground again in 2015 with 5 per cent of the translation market. Swedish has, on the other hand, advanced in the scale of importance from eighth place in the I980 to sixth place in the I990s as source language in the global translation field. Due to the Russian climb in 2015, Swedish is, however, pushed down to seventh place in that year.

Table 2 shows that domination dynamics in the global translation field are reproduced on a smaller scale within the Swedish literary space. The most dominant source languages occupy a given position even within Swedish literature, but the regional languages - Norwegian and Danish - also play a crucial role, thereby signalling the existence of a regional translation subfield, where Stockholm plays the role of centre in the regional periphery. ${ }^{20}$ This constitutes an explanation of the fact that two of the Scandinavian languages occupy a semi-peripheral position on the global translation field.

The average of translations among books published in the European countries ${ }^{21}$ amounts to I 5 per cent. ${ }^{22}$ Nonetheless, the Swedish literary space is proven the most closed in Scandinavia a decisive indication of centrality in the peripheral subfield. ${ }^{23}$ Hence the Scandinavian literary field fits the third category of four kinds of dominated languages from a global translational

${ }^{20}$ Yvonne Lindqvist, "The Scandinavian Literary Translation Field from a Global Point of View - A Peripheral (Sub)field?" in Institutions of World Literature - Writing, Translation, Markets eds. Stefan Helgesson and Pieter Vermulen (New York \& London: Routledge, 20I 5), I 8 5-87.

${ }^{21}$ Pascale Casanova, The World Republic of Letters (Cambridge: Harvard University Press, 2004), I 68.

${ }^{22}$ It has long been disputed where one should draw the line between open and closed systems based on publication statistics (cf. Bassnett I998, Pym I999). A pragmatic solution is to consider an average of 20 per cent or more as open systems.

${ }^{23}$ Lindqvist, “The Scandinavian Literary Translation Field”, I 84-86. 


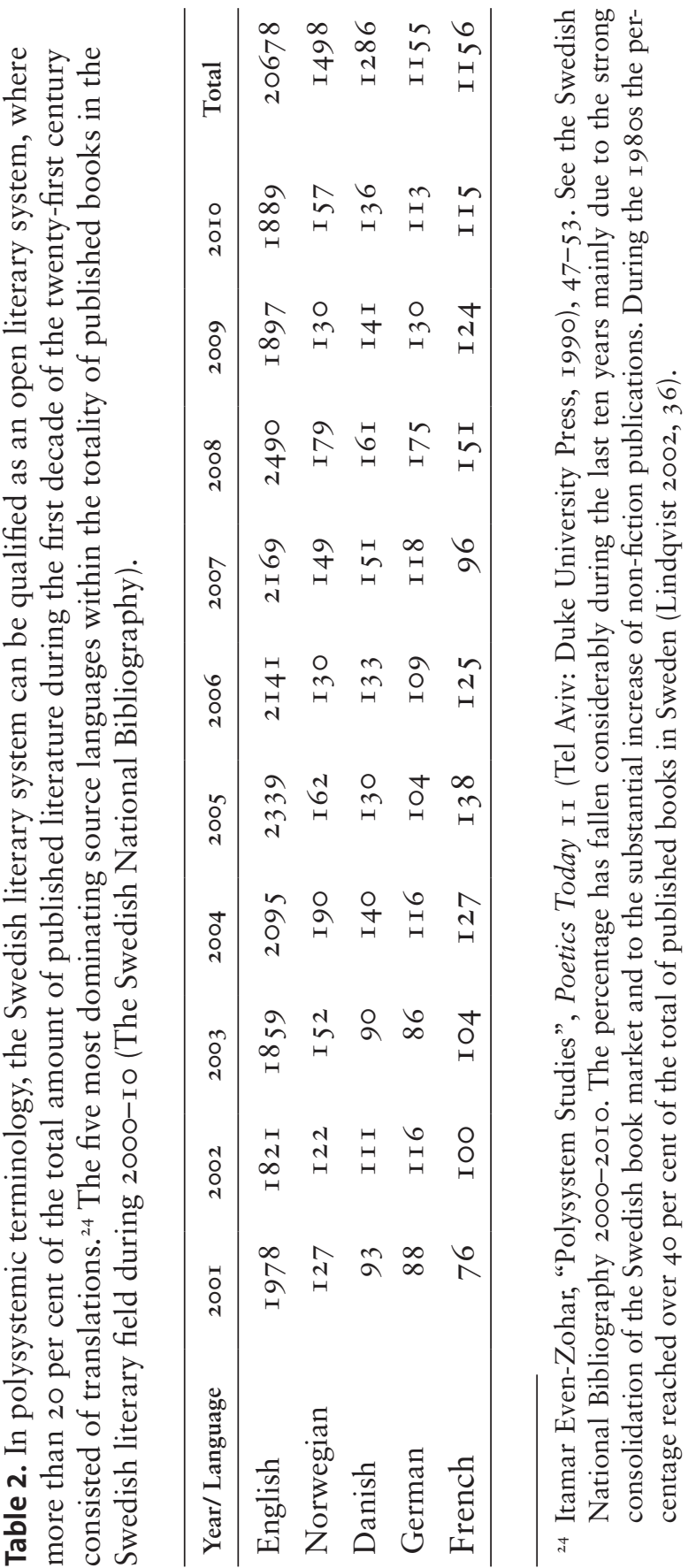


point of view discussed by Casanova. ${ }^{25}$ She distinguishes between oral languages with young writing systems and Creole languages (for example Yoruba and Haitian Creole), languages with newly gained national status (Catalan), languages of established cultures with relatively small populations (Swedish, Danish and Norwegian) and languages spoken by large populations possessing a rich literary tradition but nevertheless positioned in the very periphery of the global translation field (Hindi and Chinese). In the world republic of letters the accumulation of literary capital is decisive for the position on the global translation field. From the statistics and categorisations presented above it is possible to discern two overall orientations for literary translations on the global translation field: cosmopolitanising and vernacularising translation. ${ }^{26}$ The orientations reveal the basic bibliomigrancy dynamics of translated literature on the global translation field and are presented in Figure 6.

The central positions of dominating literatures and languages are constructed by their historically high access to literary capital and relative autonomy vis-à-vis other national literatures and languages. Cornerstones of literary capital are on the one hand the age of the literary culture and its highly specialised literary institutions, on the other literary criticism, literary values and literary renown. ${ }^{27}$ High access to literary capital means that the culture in question possesses a very well-developed literary institution and a literary repertoire, which does not need to count on translations to assert itself in competing with repertoires of other literary cultures. When a text is translated into such a culture it is considered especially valuable by the dominated cultures, which does not possess an equally developed literary repertoire. Translation in this case then becomes a proof of the high literary quality of the text. In the terminology of

\footnotetext{
25 Casanova, Consécration et accumulation, 8.

${ }^{26}$ I have schematically organised the main arguments in Casanova (2004) to create the model and adapted it to my study by adding the double consecration dynamics at the centre of my interest. The original terms in Casanova (2002:I0) are Traduction accumulation and Traduction consécration.

27 Casanova, “The World Republic", I4-I 5.
} 


\begin{tabular}{|c|c|}
\hline Cosmopolitanising translation & Vernacularising translation \\
\hline $\begin{array}{c}\text { A. Dominated } \rightarrow \text { Dominating } \\
\text { (Swedish, Danish, Norwegian } \rightarrow \\
\text { English) }\end{array}$ & $\begin{array}{c}\text { C. Dominating } \rightarrow \text { Dominated } \\
\text { (English } \rightarrow \text { Swedish, Danish, } \\
\text { Norwegian) }\end{array}$ \\
\hline $\begin{array}{c}\text { B. Dominating } \rightarrow \text { Dominating } \\
\text { (French } \rightarrow \text { Spanish) }\end{array}$ & $\begin{array}{c}\text { D. Dominated } \rightarrow \text { Dominated* } \\
\text { (Caribbean French, Spanish, English } \\
\rightarrow \\
\text { Swedish, Danish, Norwegian) }\end{array}$ \\
\hline \multirow{2}{*}{$\begin{array}{c}\text { D. Dominated } \rightarrow \text { Dominating } \rightarrow \text { Dominating } \rightarrow \text { Dominated } \\
\text { (Double consecration) }\end{array}$} \\
\hline
\end{tabular}

Figure 6. The basic bibliomigrancy dynamics on the global translation field - cosmopolitanising and vernacularising translation - with examples of relations from the involved languages of the presented project.

Bourdieu, ${ }^{28}$ this process constitutes a means for consecration of the text by the literary agents of the leading institutions of the target culture - a case of cosmopolitanising translation. A typical example of a cosmopolitansing translation is shown in figure 6, case A, when Scandinavian, i.e. Swedish, Danish and Norwegian, crime fiction novels translated into English are launched into the AngloAmerican market. The novels then gain in literary prestige, accumulating literary capital by the consecration, and consequently become more interesting for other dominating literary cultures, for instance the French culture. A famous example from Swedish crime fiction is the Millennium Trilogy by Stieg Larsson, in 2009 sold in Io million copies. ${ }^{29}$ Other examples of Scandinavian peripheral writers in cosmopolitanising translation are the Norwegian Torkil Damhaug's Oslo Crime Files Quartet and the Danish writer Jussi Adler-Olsen winner of the Glas Key Prize in 2010 for best Scandinavian crime fiction novel.

Case B in figure 6 shows another dynamic of cosmopolitanising translation - translation taking place between two dominating cultures, for instance between the French and Spanish literary

${ }_{28}$ Bourdieu, "Konstens regler", 326-27.

29 Erica Treijs, "Litteraturens ansikte”, Svenska Dagbladet, I I September 2009. 
cultures. It is highly probable that the French Goncourt Prizewinner will be translated into Spanish and reversely that the Nadal Prize-winner will be translated into French. Consequently, the Goncourt Prize-winner of 2010, Michel Houellebecq with the novel La carte et le territoire, for instance, was translated into Spanish in $20 \mathrm{I} 2$ under the title La mapa y el territorio. And Clara Sánchez, The Nadal Prize winner of 2010 with the novel Lo que esconde tu nombre, which was translated into French under the title Ce que cache ton nom in 2012.

The position of the dominated literatures and languages on the global translation field is, on the other hand, due to their lack of literary capital and relative autonomy. The translation relations occurring in these cultures are vernacularising translations, i.e. translations stemming from the dominant positions and languages. A prototypical example of vernacularising translation is from English to Swedish, case C in figure 6. As we have seen in table 2, this translation relation is by large the most common relationship in Sweden. In fact, 7 I per cent of all published translations in Sweden during the period 2000-20I0 had English as source language. $3^{\circ}$ The dynamics of English source language translations are very similar in Norway and Denmark ${ }^{31}$ (a veritable wave in the Moretti sense ${ }^{32}$ ).

Case $\mathrm{D}$ in figure 6 - the vernacularising translation in focus in the project - is elucidated in case $D^{*}$ and illustrates the double consecration hypothesis. That is, in order for two literary peripheries on the global translation field - the Caribbean and the Scandinavian - to meet by means of translation, the migrating source texts have to be primarily consecrated within two central literary cultures, revealing cosmopolitanising dynamics in vernacularising translation as well. This is probably the prerequisite for Scandinavian publisher's decision to publish French, Spanish and English Caribbean writers in translation. Proceeding from this theoretical framework the project will examine the multidirectional dynamics of cosmopolitanising and vernacularising translation on the global translation field.

\footnotetext{
30 Swedish National Bibliography, 2000-20I0.

${ }^{1}$ L Lindqvist, "The Scandinavian”, I 80-83.

32 Franco Moretti, “Conjectures on World Literature”, New Left Review I (2000): 67 .
} 


\section{Bibliography}

Baker, Mona. "Editor's Introduction. Chapter I 6". In Critical Readings in Translation Studies, edited by Mona Baker, 28 5-86. London and New York: Routledge, 20Iо.

Batchelor, Kathryn. "Translation: Spreading The Wings of Literature. Veronique Tadjo in Interview with Kathryn Batchelor". In Intimate Enemies: Translation in Francophone Contexts, edited by Kathryn Batchelor and Claire Bisdorf, 98-г08. Liverpool: Liverpool University Press, 20I3.

Cheah, Pheng. "What is a World? On World Literature as WorldMaking Activity". Doedalus 3 (2008): 26-38.

Bourdieu, Pierre. The Field of Cultural Production: Essays on Art and Literature. Cambridge: Polity Press, I993.

—. Kultur och kritik. Göteborg: Daidalos. I997.

- Konstens regler: Det litterära fältets uppkomst och struktur. Translated by Johan Stierna. Stockholm: Symposion, 2000.

Casanova, Pascale. La République mondiale des lettres. Paris: Éditions du Seuil, I999.

—. "Consécration et accumulation de capital littéraire. La traduction come échange inégal". Actes de la recherche en sciences sociales I44 (2002): 7-20.

Casanova, Pascale. The World Republic of Letters. Translated by M. B. DeBevoise. Cambridge: Harvard University Press, 2004.

Casanova, Pascale. "Literature as a World". New Left Review $3 \mathrm{I}$ (2005): 7I-90.

Chesterman, Andrew. "The Name and Nature of Translator Studies". Hermes 42. 2009. I3-22.

Even-Zohar, Itamar. "Polysystem Studies". Poetics Today I I, no. I (I990).

Heilbron, Johan. "Towards a Sociology of Translation: Book Translations as a Cultural World System". European Journal of Social Theory 2, no. 4 (I999): 429-44. 
- "Responding to Globalization. The Development of Book Translations in France and the Netherlands". In Beyond Descriptive Translation Studies. Investigations in Homage to Gideon Toury, edited by Anthony Pym, Miriam Shlesinger and Daniel Simeoni, I 87-99. Amsterdam/Philadelphia: Benjamins, 2008.

Lindqvist, Yvonne. Översättning som social praktik. Toni Morrison och Harlequinserien. Passion pà svenska. Diss. Stockholm Studies in Scandinavian Philology. N.S. 26. Stockholm: Almqvist \& Wiksell International. 2002.

"Det globala översättningsfältet och den svenska översättningsmarknaden. Förutsättningar för litterära periferiers möte”. In Läsarnas marknad, marknadens läsare. En forskningsantologi utarbetad för litteraturutredningen, edited by Ulla Carlsson and Jenni Johannisson, I97-209. NORDICOM. Göteborg: Göteborgs universitet, $20 \mathrm{I} 2$.

- "The Scandinavian Literary Translation Field from a Global Point of View - A Peripheral (Sub)field?" In Institutions of World Literature: Writing, Translation, Markets, edited by Stefan Helgesson and Pieter Vermulen, I74-87. New York: Routledge, 2015 .

Mani, Venkat. Bibliomigrancy: "Book Series and the Making of World Literature". In The Routledge Companion to World Literature, edited by Teo D'haen, David Damrosch, Djelal Kadir, 283-96. New York: Routledge, 20I4.

Moretti, Franco. "Conjectures on World Literature". New Left Review I (2000): 54-68.

"More conjectures". New Left Review 20 (2003): 73-8 I.

Treijs, Erica. "Litteraturens ansikte". Svenska Dagbladet II September 2009.

Sapiro, Gisèle Translatio: Le marché de la traduction en France à l'heure de la mondialisation. Paris: CNRS, 2008.

. "Globalization and Cultural Diversity in the Book Market: The Case of Literary Translations in the US and in France". Poetics 38 (2010): 4I9-39. 
Svedjedal, Johan, ed. Svensk litteratur som världslitteratur: en antologi. Uppsala: Uppsala University, 20 2.

Wilson, Emily. "Translating the Classics". Society for Classical Studies 20I4. http://apaclassics.org/blogs/emily_wilson/translating-classics\#sthash.rUe8ppAı.dpuf. Accessed I6 October 20 I6.

Wolf, Michaela. "Translating and Interpreting as a Social Practice Introspection into a New Field". In Übersetzen-TranslatingTraduire: Towards a "Social Turn"?, edited by Michaela Wolf, 9-23. London: Transaction Publishers, 2006. 